\title{
PLASMA PROGESTERONE CONCENTRATIONS DURING PREGNANCY AND LACTATION IN THE RAT
}

\author{
LEE J. GROTA* AND KRISTEN B. EIK-NES \\ Department of Biological Chemistry, University of Utah College of Medicine, \\ Salt Lake City, Utah, U.S.A.
}

(Received 13th Fanuary 1966, revised 28th March 1966)

\begin{abstract}
Summary. Plasma progesterone concentrations in rats were determined by a method employing gas-liquid chromatography with electron capture detection. Progesterone concentration was found to decrease before parturition and to increase again during lactation. A maximal post-partum concentration of this hormone was found during the 4th day of lactation. Removal of the litter or the placenta at delivery resulted in a decrease in the progesterone concentration at this time. Injection of large doses of prolactin in hypophysectomized female rats was associated with an increase in plasma progesterone concentration.
\end{abstract}

\section{INTRODUCTION}

During the last few years several papers have appeared reviewing the role of the endocrine glands in pregnancy. The authors (Catchpole, 1959; Zarrow, 1961 ; Nalbandov, 1961; Short, 1961; Diczfalusy, 1964) have all indicated that the major steriod hormones of pregnancy are progesterone, oestrogens, the adrenocorticoids and aldosterone. The evidence that progesterone is a hormone of this physiological condition includes maintenance of pregnancy in ovariectomized animals by treatment with progesterone, a gradual rise in plasma progesterone during pregnancy, and the isolation of large amounts of progesterone from the placentae of some species. It is generally held that there is a decrease in progesterone production near term of pregnancy. Such a decrease could allow the uterus to respond to the posterior pituitary hormone, oxytocin, and expel the foetus. Injection of progesterone in pregnant animals will maintain pregnancy beyond the normal time of term and immediately following the withdrawal of progesterone parturition is initiated. However, when methods for the determination of plasma concentrations of progesterone became available, a number of studies were published which showed that plasma progesterone did not fall until or after parturition in some animal species (Short, 1961; Zarrow, 1961).

Lactation and maternal care of the offspring normally follow termination of pregnancy. Oestrogens appear to be a major requirement for growth of

* Present address: Department of Psychiatry, University of Rochester School of Medicine and Dentistry, Rochester, New York. 
mammary ducts while progesterone is needed for lobulo-alveolar tissue development (Cowie \& Folley, 1961). In ovariectomized, hypophysectomized and adrenalectomized rats, the combined treatment with oestrogen, growth hormone and corticoids results in duct proliferation while, for the development of lobulo-alveolar tissue, addition of progesterone and prolactin is required. Milk secretion in such animals can be accomplished with prolactin and corticoid treatment alone. In the normal rat, adrenocorticotrophin (ACTH) and prolactin are both required for lactation in an adequately developed mammary gland and suckling appears to be the stimulus for the maintenance of lactation. Meites, Nicoll \& Talwalker (1963) indicate that the response to suckling is release of pituitary prolactin, АCTH, anti-diuretic hormone and oxytocin. Meites et al. have also reviewed the evidence suggesting that prolactin is luteotrophic in the rat.

Recently, very sensitive methods utilizing gas-liquid chromatography with electron capture detection have become available for the analysis of small amounts of steriods in blood (Brownie, van der Molen, Nishizawa \& Eik-Nes, 1964; van der Molen \& Groen, 1965; Eik-Nes, Aakvaag \& Grota, 1965). The purpose of the present investigation was to examine the plasma concentration of progesterone, oestradiol and testosterone during pregnancy and lactation in the rat. Special emphasis was placed on studying the plasma concentration of these hormones in lactating animals since this aspect of endocrinology is at best ill-explored. Denenberg, Grota \& Zarrow (1963) have shown that the survival of newborn fostered young is enhanced when the mother eats placentae presented with the young. It is also known that the presence of the litter affects the lactational competence of the rat (Meites et al., 1963). A second purpose of our investigation was, thus, to examine the effects of placentophagy and the presence of litters on plasma progesterone concentration in the postpartum rat.

\section{MATERIALS AND METHODS}

All reagents were purified as discussed in previous publications (Brownie et al., 1964; van der Molen \& Groen, 1965; Eik-Nes et al., 1965).

\section{Steroid determination}

To an $80-\mathrm{ml}$ tube containing from 2 to $6 \mathrm{ml}$ rat plasma were added 15,000 $\mathrm{dpm}$ of $7-{ }^{3} \mathrm{H}$-progesterone $(2 \mathrm{c} / \mathrm{mm})$ and $15,000 \mathrm{dpm}$ of $7-{ }^{3} \mathrm{H}$-corticosterone $(500 \mathrm{mc} / \mathrm{mm}$ ) and the sample was diluted to $10 \mathrm{ml}$ with $0.9 \%$ sodium chloride. A blank of $10 \mathrm{ml} 0.9 \%$ sodium chloride was taken through the entire method with each series of unknown plasma samples. The samples were extracted with $20 \mathrm{ml}$ methylene dichloride once followed by three extractions with $10 \mathrm{ml}$ of methylene dichloride. The combined extract was dried down in nitrogen and the residue chromatographed on paper strips in hexane-formamide keeping the chromatograms in the chromatography tank $2 \mathrm{hr}$ after the solvent had reached the end of the strip. On parallel strips were chromatographed authentic progesterone and corticosterone. These standards were located on the paper strips as previously described by our laboratory (van der Molen \& Groen, 
1965). Two areas were eluted from the chromatogram of each plasma sample: one chromatographing like authentic progesterone and a second one chromatographing like authentic corticosterone. This second area was at the origin of the chromatogram and could also include testosterone, oestradiol and other more polar steroids.

The eluted progesterone-like material was dried down in nitrogen and the residue processed for progesterone as described by van der Molen \& Groen (1965).

The second area eluted from the paper strip was chromatographed on a thin-layer plate in the solvent system benzene-ethyl acetate $(1: 1, \mathrm{v} / \mathrm{v})$ chromatographing authentic corticosterone, testosterone and oestradiol on separate lanes. Corticosterone and testosterone were located as previously described (van der Molen, Runnebaum, Nishizawa, Kristensen, Kirschbaum, Wiest \& Eik-Nes, 1965) and oestradiol was spotted by iodine vapour (Matthews, Perida \& Aguilera, 1962).

Material in the plasma sample chromatographing like authentic oestradiol or testosterone was scraped off the plate and eluted with methanol. The thin-layer plate was then chromatographed in the solvent system benzeneacetone $(1: 1, \mathrm{v} / \mathrm{v})$ until the solvent reached the middle of the plate. The plasma material chromatographing like authentic corticosterone was scraped off and eluted with $3 \mathrm{ml}$ of butanol-methanol $(1: 3, \mathrm{v} / \mathrm{v})$ three times. The eluate was dried down in nitrogen, the residue dissolved in methanol and a $0 \cdot 1$ aliquot was removed for the counting of radioactivity by liquid scintillation spectrometry (Hall, Sozer \& Eik-Nes, 1964). The remaining methanol was dried down under nitrogen and the residue exposed to the copper acetate-Porter-Silber reaction described by Lewbart \& Mattox (1960) for the estimation of 17-deoxycorticoids. Data from this part of our investigation will be reported elsewhere.

Since testosterone could not be quantitated adequately in individual samples of from 4 to $8 \mathrm{ml}$ of plasma from pregnant or lactating animals by the method of Brownie et al. (1964), plasma testosterone-like material (as judged by criteria of behaviour in thin-layer chromatography) from groups of animals (see below) was pooled, $15,000 \mathrm{dpm}$ of $7{ }^{3} \mathrm{H}$-testosterone added to each pool and the sample dried down under nitrogen. The residue was processed for testosterone as described by our laboratory (Brownie et al., 1964).

In trial examinations, oestradiol could not be found in from 6 to $10 \mathrm{ml}$ of rat plasma by the method used (Eik-Nes et al., 1965). The oestradiol-like material in the plasma of animals from the same group was pooled, 15,000 dpm of $7-{ }^{3} \mathrm{H}$-oestradiol added to each pool, and the sample processed for oestradiol as described by Eik-Nes et al. (1965).

\section{Animals}

Both normal and pregnant rats were purchased from Holtzman Company (Madison, Wisconsin). The normal female rats were mated in our own laboratory. The presence of spermatozoa in the vagina defined Day 1 of pregnancy. Hypophysectomized female rats were purchased from the Hormone Assay Laboratory (Chicago, Illinois) and used 24 to $36 \mathrm{hr}$ after surgery.

All animals were housed in $11 \times 11 \times 6 \frac{1}{2}$ in. clear plastic cages and were given 
unlimited food and water. At the appropriate time, the animal was decapitated and the blood collected in a heparinized tube. The blood was centrifuged immediately, the plasma removed and frozen. No sample was frozen for more than 4 weeks before steriod analysis.

The initial experiment was designed to determine the plasma concentration of corticosterone, progesterone, oestradiol and testosterone at 08.00 hours on on the 18th, 21st and 22nd (term) day of pregnancy and at $6 \mathrm{hr}, 12 \mathrm{hr}, 1,2,4$ and 8 days post partum. Additional assays for progesterone alone were done at 14.00 hours and 20.00 hours on the 21 st day of pregnancy and also at 02.00 hours on the 22nd day of pregnancy.

In a second experiment, the effects of the presence of litters and placentophagy on plasma progesterone concentration were assessed in a $2 \times 2$ factorial design. Placentae and/or litters were removed during normal delivery. Four days post partum, the animals were decapitated, blood collected and processed as described previously.

The third experiment was designed to determine the luteotrophic properties of prolactin. Hypophysectomized female rats were divided into two groups, one group received $10 \mathrm{mg}$ of prolactin (NIH-P-s6, $24.8 \mu / \mathrm{mg}$ ) in $1 \mathrm{ml} \mathrm{of} 0.9 \%$ sodium chloride subcutaneously and a second group received $10 \mathrm{mg}$ of electrophoretically pure bovine serum albumin (Calbiochem, Los Angeles, California) in $1 \mathrm{ml}$ of sodium chloride subcutaneously. Animals in each group were killed 1, 2, 4 and $8 \mathrm{hr}$ after injection, the blood collected and analysed for progesterone.

TABLE 1

RECOVERY OF AUTHENTIC STEROIDS

\begin{tabular}{c|c|c|c}
\hline \multirow{2}{*}{ Steroid } & Amount added/ml water $(\mathrm{ng})$ & Amount found/ml water* & No. of experiments \\
\cline { 2 - 4 } Progesterone & 190 & $186 \mathrm{ng} \pm 4 \cdot 75$ & 7 \\
& 19 & $18 \mathrm{ng} \pm 17 \cdot 19$ & 8 \\
\hline
\end{tabular}

* Mean level and one standard error of this mean (expressed as percentage).

\section{RESULTS}

\section{Recovery of steroids}

In order to assess the reliability of the methods used, known amounts of progesterone were added to $5 \mathrm{ml}$ water and these water samples assayed by the method described. The concentrations of authentic steroid were selected to cover the concentrations expected in about $5 \mathrm{ml}$ of rat plasma. An cxamination of the data in Table 1 indicates that the progesterone method at both high and low levels of progesterone is sufficiently accurate to be utilized for the determination of plasma concentrations of this hormone in the rat.

\section{Plasma testosterone and oestradiol}

Plasma concentrations of oestradiol and testosterone are tabulated in Table 2 for the different conditions investigated. Although large amounts of plasma 
were pooled (from 22 to $38 \mathrm{ml}$ ) in each group of animals, oestradiol concentrations were too low to be detected with any degree of accuracy. This was also the case for plasma testosterone levels.

TABLE 2

MEAN PLASMA CONGENTRATION OF TESTOSTERONE AND OESTRADIOL IN RATS DURING LATE PREGNANGY AND

EARLY LAGTATION

\begin{tabular}{|c|c|c|c|}
\hline \multirow[b]{2}{*}{ Condition } & \multicolumn{2}{|c|}{ Pooled samples of plasma } & \multirow{2}{*}{$\begin{array}{c}\text { Plasma used for } \\
\text { assay } \\
(m l)\end{array}$} \\
\hline & $\begin{array}{c}\text { Testosterone } \\
(n g / m l)\end{array}$ & $\begin{array}{c}\text { Oestradiol } \\
(n g / m l)\end{array}$ & \\
\hline $\begin{array}{l}\text { Day of pregnancy } \\
\text { 18th } \\
21 \mathrm{st} \\
22 \mathrm{nd}\end{array}$ & $\begin{array}{l}1.0 \\
\text { Lost } \\
0.7\end{array}$ & $\begin{array}{l}3.1 \\
\text { N.D. } \\
\text { N.D. }\end{array}$ & $\begin{array}{l}25 \cdot 0 \\
33 \cdot 8 \\
34 \cdot 0\end{array}$ \\
\hline $\begin{array}{l}\text { Post partum } \\
6 \mathrm{hr} \\
12 \mathrm{hr} \\
1 \text { day } \\
2 \text { days } \\
4 \text { days } \\
8 \text { days }\end{array}$ & $\begin{array}{l}0 \cdot 8 \\
0 \cdot 6 \\
0 \cdot 4 \\
0 \cdot 7 \\
1 \cdot 1 \\
0 \cdot 9\end{array}$ & $\begin{array}{c}\text { N.D. } \\
7 \cdot 2 \\
2 \cdot 1 \\
\text { N.D. } \\
3 \cdot 0 \\
2 \cdot 8\end{array}$ & $\begin{array}{l}32 \cdot 2 \\
27 \cdot 4 \\
38 \cdot 3 \\
32 \cdot 7 \\
31 \cdot 0 \\
22 \cdot 4\end{array}$ \\
\hline
\end{tabular}

N.D., Not detectable in the pool of plasma used.

TABLE 3

'LUTEOTROPHIC PROPERTIES' OF 'PLACENTOPHAGY' AND PRESENCE OR ABSENCE OF LITTERS ON MEAN PLASMA CONGENTRATIONS OF PROGESTERONE IN RATS ON THE FOURTH DAY OF LACTATION

\begin{tabular}{l|c}
\hline \multicolumn{1}{c|}{ Condition } & $\begin{array}{c}\text { Progesterone } \\
(\text { ng/ml plasma })^{*}\end{array}$ \\
\hline $\begin{array}{l}\text { Placenta consumed } \\
\text { Litters present }\end{array}$ & $122 \pm 33 \cdot 0$ \\
Placenta consumed & $(6)$ \\
No litters present & $42 \pm 14.5$ \\
Placenta not consumed & $62 \pm 5 \cdot 5$ \\
Litters present & $\frac{(6)}{(6)}$ \\
Placenta not consumed & $14 \pm 14 \cdot 2$ \\
No litters present & $(3)$ \\
\hline
\end{tabular}

* Mean values and one standard error of the mean are given. The number in parentheses refers to number of animals in each group.

\section{Progesterone}

Analysis of plasma progesterone levels during pregnancy and lactation indicated that there was a gradual decrease in the concentration of the hormone as term of pregnancy approached followed by an increase during lactation 
(Text-fig. 1). In the $24 \mathrm{hr}$ preceding parturition (Day 22 of pregnancy), the concentration of progesterone decreased significantly from $114 \mathrm{ng} / \mathrm{ml}$ of plasma (at 08.00 hours on Day 21) to $10 \mathrm{ng} / \mathrm{ml}$ of plasma at 08.00 hours on Day 22 $(F=7.41, \mathrm{df}=4,20, P<0.01)$. Within $6 \mathrm{hr}$ post partum, the plasma progesterone concentration rose to $43 \mathrm{ng} / \mathrm{ml}$ and remained at this level until 2 days after delivery. After this time there was a rise in progesterone concentration to $123 \mathrm{ng} / \mathrm{ml}$ of plasma on Day 4 of lactation. The concentration of progesterone remained at this new level until at least the 8th day of lactation.

The effects of placentophagy at delivery and of the presence or absence of offspring on plasma progesterone concentration during lactation can be assessed by analysing the data presented in Table 3 . Removal of the litter at birth resulted in a significant decrease in plasma progesterone concentration $(F=$ $8.34, \mathrm{df}=1,18, P<0.01$ ). The removal of the placenta at delivery was associated with a decrease in progesterone concentration which approached significance $(F=3.94, \mathrm{df}=1,18, P<0 \cdot 10)$.

TABLE 4

A POSSIBLE LUTEOTROPHIC EFFECT OF PROLACTIN IN HYPOPHYSECTOMIZED FEMALE RATS

\begin{tabular}{c|c|c|c|c}
\hline \multirow{3}{*}{$\begin{array}{c}\text { Hours } \\
\text { after } \\
\text { treatment }\end{array}$} & \multicolumn{2}{|c|}{$\begin{array}{c}\text { Administration of } \\
\text { prolactin }\end{array}$} & \multicolumn{2}{|c}{$\begin{array}{c}\text { Administration of } \\
\text { bovine serum albumin }\end{array}$} \\
\cline { 2 - 3 } & $\begin{array}{c}\text { Progesterone } \\
\text { (ng/ml plasma) }\end{array}$ & $\begin{array}{c}\text { No. of } \\
\text { animals }\end{array}$ & $\begin{array}{c}\text { Progesterone } \\
\text { (ng/ml plasma) }\end{array}$ & $\begin{array}{c}\text { No of } \\
\text { animals }\end{array}$ \\
\hline 1 & 112 & 2 & 37 & 3 \\
2 & 50 & 3 & N.D. & 2 \\
4 & 48 & 3 & 7 & 2 \\
8 & 30 & 2 & N.D. & 3 \\
\hline
\end{tabular}

Mean levels of progesterone ( $\mathrm{ng} / \mathrm{ml}$ plasma) are given. N.D., Not detectable.

Administration of prolactin to hypophysectomized female rats gave higher concentrations of plasma progesterone than administration of bovine serum albumin (Table 4). The highest concentration of plasma progesterone was found within $1 \mathrm{hr}$ after administration of prolactin although some effects on plasma progesterone were noted even $8 \mathrm{hr}$ after treatment $(112$ and $30 \mathrm{ng} / \mathrm{ml}$ of plasma respectively). Since no estimate was made of plasma progesterone before the administration of bovine serum albumin, it is not known whether the mean level of $37 \mathrm{ng}$ progesterone/ml plasma $1 \mathrm{hr}$ after the administration of the protein is due to a possible residual concentration of plasma progesterone or to an effect of serum albumin injection.

\section{DISCUSSION}

The finding that there is a decrease in progesterone concentration in peripheral blood before parturition (Text-fig. 1) is in agreement with the data of Eto, Masuda, Shzuki \& Hosi (1962) assaying progesterone in ovarian vein blood of the pregnant rat. These data are consistent with the hypothesis that high 
concentrations of progesterone may prevent the onset of parturition and that parturition begins when the progesterone concentration falls.

Indirect evidence that prolactin is luteotrophic in the rat has been available for some time (Meites et al., 1963). Our observation that progesterone concentration in plasma is increased at the beginning of lactation (Text-fig. 1) is further support for this view. Moreover, some trophic effect for prolactin

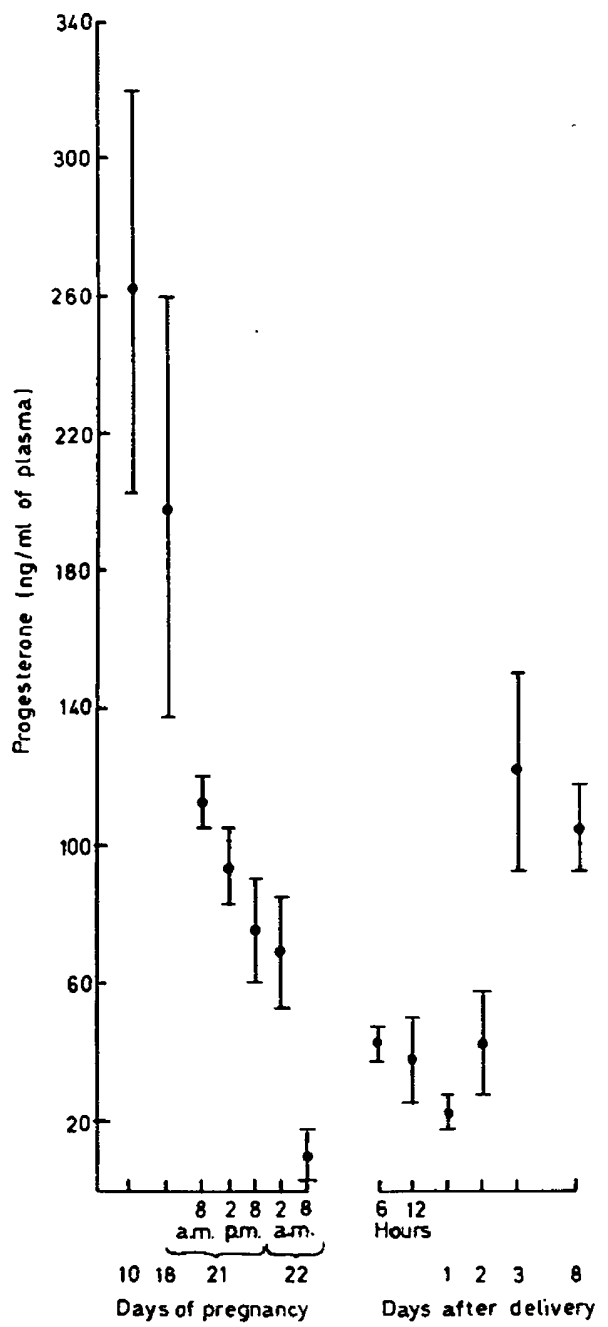

TEXT-FIG. 1. Mean plasma levels of progesterone in pregnant and lactating rats. I, One standard error of the mean.

could be demonstrated in the rat since prolactin injections in hypophysectomized animals were associated with an increase in plasma progesterone concentrations. These latter data, however, should be evaluated with considerable care since large doses of prolactin were used in our experiment. The information of Text-fig. 1 and of Table 4, taken together, is consistent with the theory that prolactin stimulates the rat ovary. The nature of this apparent trophic effect of 
prolactin and of lactation cannot be determined from our data. It is, however, of interest to note that if the litters are removed from the mothers at birth, plasma progesterone levels are lower on the 4th day post partum than in animals permitted to keep their litters (Table 3). These data point to suckling as a stimulus for high post-partum levels of progesterone, a view by no means incompatible with that expressed by Meites and his co-workers (Meites et al., 1963).

Removal of the placenta at delivery also results in a decrease in progesterone concentration 4 days post partum (Table 3). Denenberg et al. (1963) have shown that removal of the placenta before fostering newborn rats results in a decrease in the number of fostered offspring surviving. Offspring survival was used as an index of maternal behaviour. Thus, these data suggest the hypothesis that progesterone may play an important role in the initiation of maternal behaviour. The amount of progesterone in the placenta was not determined in our experiments, but it seems unlikely that the amount of placental progesterone is sufficient for the changes in plasma concentration observed in rats permitted to consume the placenta post partum. Our findings indicate that both placentophagy and presence of litters are essential for the changes in plasma progesterone observed following parturition.

\section{ACKNOWLEDGMENTS}

This work was supported in part by U.S. Public Health training Grant T4 CA 5000 and by U.S. Public Health research Grant AM 06651.

\section{REFERENCES}

Brownie, A. C., van der Molen, H. J., Nishizawa, E. E. \& Eik-Nes, K. B. (1964) Determination of testosterone in human peripheral blood using gas-liquid chromatography with electron capture detection. 7. clin. Endocr. Metab. 24, 1091.

CAtchpole, H. R. (1959) Endocrine mechanisms in pregnancy. Reproduction in Domestic Animals. Eds. H. H. Cole and P. T. Cupps. Academic Press, New York.

Cowie, A. T. \& Folley, S. J. (1961) The mammary gland and lactation. Sex and Internal Secretions, p. 590. Ed. W. G. Young. Williams \& Wilkins, Baltimore.

Denenberg, V. H., Grota, L. J. \& Zarrow, M. X. (1963) Maternal behaviour in the rat: analysis of cross-fostering. 7. Reprod. Fert. 5, 133.

Diczfalusy, E. (1964) Endocrine functions of the human fetal-placental unit. Fedn Proc. Fedn Am. Socs exp. Biol. 23, 791.

Eik-Nes, K. B., AAKVAaG, A. \& Grota, L. J. (1965) Estimation of estradiol $17 \beta$ by gas-liquid chromatography with electron capture detection. Gas Chromatography of Steroids in Biological Fluids, p. 247. Ed. M. B. Lipsett. Plenum Press, New York.

Eto, T., Masuda, H., Shzuki, Y. \& Hosi, T. (1962) Progesterone and pregn-4-ene 20x-ol-3-one in rat ovarian venous blood at different stages in the reproductive cycle. 7ap. F. Anim. Reprod. 8, 34.

HaLl, P. F., SozER, C. C. \& EIK-Nes, K. B. (1964) Formation of dehydroepiandrosterone during in vivo and in vitro biosynthesis of testosterone by testicular tissue. Endocrinology, 74, 35.

Lewbart, M. L. \& Mattox, V. R. (1960) Extension of the Porter-Silber reaction to a-ketolic steroids lacking a hydroxyl group at $\mathrm{C}_{17}$. Fedn Proc. Fedn Am. Socs exp. Biol. 19, 158.

Matthews, J. S., Perida, V. A. L. \& Aguilera, P. A. (1962) Steroids. CCXV. The quantitative analysis of steroids by thin-layer chromatography. F. Chromat. 9, 331 .

Meites, J., Nicoll, C. S. \& Talwalker, P. K. (1963) The central nervous system and the secretion and release of prolactin. Advances in Neuroendocrinology, p. 238. Ed. A. V. Nalbandov. University of Illinois Press, Urbana.

Nalbandov, A. V. (1961) Comparative physiology and endocrinology of domestic animals. Recent Prog. Horm. Res. 17, 119. 
Short, R. V. (1961) Progesterone. Hormones in Blood, p. 379. Eds. C. H. Gray and A. L. Bacharach. Academic Press, New York.

van der Molen, H. J. \& Groen, D. (1965) Determination of progesterone in human peripheral blood using gas-liquid chromatography with electron capture detection. Gas Chromatography of Steroids in Biological Fluids, p. 153. Ed. M. B. Lipsett. Plenum Press, New York.

van der Molen, H. J., Runnebaum, B. Nishizawa, E. E., Kristensen, E., Kirschbaum, T., Wiest, W. G. \& Eik-Nes, K. B. (1965) On the presence of progesterone in blood plasma from normal women. 7. clin. Endocr. Metab. 25, 170.

Zarrow, M. X. (1961) Gestation. Sex and Internal Secretions, p. 958. Ed. W. C. Young. Williams \& Wilkins, Baltimore. 